\title{
透過電子顕微鏡によるステレオ観察の計測精度
}

\author{
丹羽崇文*1 池松陽一*2 谷山 明*3 進 藤大輔*4
}

東北大学素材工学研究所

J. Japan Inst. Metals, Vol. 67, No. 2 (2003), pp. 93-97

(C) 2003 The Japan Institute of Metals

\section{Accuracy of Measurements in Stereoscopic Observation by Using Transmission Electron Microscope}

Takafumi Niwa*1, Yoichi Ikematsu*2, Akira Taniyama*3 and Daisuke Shindo*4

Institute for Advanced Materials Processing, Tohoku University, Sendai 980-8577

To evaluate the accuracy of measurements using stereoscopic observation employing a transmission electron microscope (TEM), the thickness $(\sim 0.6 \mu \mathrm{m})$ of platelet-type $\alpha-\mathrm{Fe}_{2} \mathrm{O}_{3}$ particles was investigated by stereoscopic observation using TEMs and imaging plates. The accuracy of these measurements was evaluated by comparing $t_{\mathrm{s}}$ with $t_{\mathrm{g}}$, where $t_{\mathrm{s}}$ and $t_{\mathrm{g}}$ were the thicknesses determined by stereoscopic observation and geometric calculation taking the particle's shape into account, respectively. The standard deviation of the difference between $t_{\mathrm{s}}$ and $t_{\mathrm{g}}$ decreases with increased tilt angle up to $20^{\circ}$. The minimum standard deviation of the difference was evaluated to be $4.8 \%$ at a tilt angle of $20^{\circ}$. From the present study, it was found that a particle's shape, such as thickness on a sub-micrometer scale, can be evaluated by stereoscopic observation using a TEM set at the highest accuracy at a tilt angle of about $20^{\circ}$.

(Received September 10, 2002; Accepted December 16, 2002)

Keywords: stereoscopic observation, transmission electron microscopy, platelet-type $\alpha-\mathrm{Fe}_{2} \mathrm{O}_{3}$ particles, imaging plate, specimen thickness

\section{1. 緒言}

透過電子顕微鏡 $($ TEM : Transmission Electron Microscope)は, 従来より微小領域における材料の形態や結晶構造 を明らかにする評価装置として種々の先端材料の構造解析に 応用されている11. TEM を用いたステレオ観察は, 傾斜角 を変えて撮影された一対の TEM 像を, ステレオビューワー などを用いて立体視する方法であり, 結晶における微小欠陥 の 3 次元分布の解析や微粒子の形態評価に応用されてき た ${ }^{2)}$.この TEM によるステレオ観察では, 主に写真フィル ムに撮影された, あるいは印画紙に焼き付けられた電顕画像 を人間の目によって定性的に評価する方法が行われてきた. このため, TEM を用いたステレオ観察の寸法計測における 計測精度は，これまで殆ど不明のままであった。

*1 東北大学大学院生, 現在 : 東京エレクトロン九州秼プロセス技 術部 (Graduate Student, Tohoku University, Present address: Process Technology Dept., Tokyo Electron Kyushu Ltd.)

*2 現在 : 新日本製鐵株式会社先端技術研究所 (Present address: Advanced Technology Research Laboratories, Nippon Steel Corp.)

*3 現在 : 住友金属工業株式会社総合技術研究所 (Present address: Corporate Research and Development Laboratories, Sumitomo Metal Industries, Ltd.)

*4 現在 : 東北大学多元物質科学研究所 (Present address: Institute of Multidisciplinary Research for Advanced Materials, Tohoku University)
イメージングプレートは, 電顕画像をディジタルデータと して取り扱うことが可能である ${ }^{3-6)}$. このデジタルデータと なった電顕画像をコンピューターの画面上に表示させ, 適切 なソフトウエアを用いることにより，より客観的な寸法計測 が可能である. 従って, ステレオ観察により得られる TEM 像をイメージングプレートに記録することにより，従来の写 真フィルムで評価が困難とされていたステレオ観察における 寸法計測の計測精度をより定量的に検討できるものと考えら れる.

本論文では，TEM とイメージングプレートを用いたステ レオ観察法により六角盤状へマタイト微粒子の厚みを評価 し, 粒子形状を考慮した幾何学計算により得られるへマタイ 卜微粒子の厚みと比較することにより，ステレオ観察におけ る計測精度を評価した。ささに，粒子厚みの計測精度に及ぼ す傾斜角度の影響を把握することにより，TEM を用いたス テレオ観察による寸法計測の最適傾斜角について検討を行っ た。

\section{2. 実 験 方 法}

\section{1 六角盤状へマタイト微粒子の作製および TEM 観察}

ステレオ観察に用いた六角盤状へマタイト微粒子の合成条 件は，ゾルーゲル法で作製されたものであり，東北大学多元 物質科学研究所 杉本忠夫教授に提供頂いた.ゾルーゲル法 による六角盤状へマタイト微粒子の合成条件の詳細について 
は，文献(7)を参照されたい。この粉末状のへマタイト微粒 子をブタノール中に分散させた後, $\phi 3 \mathrm{~mm}$ のマイクログリ ッド上に支持し，自然乾燥後 TEM 観察に供した.

ステレオ観察には，加速電圧 $200 \mathrm{kV}$ の TEM (日本電子製 JEM-2010 および JEM-2000EX) を用いた．TEM 像の撮影 には，富士写真フィルム製のイメージングプレート (FDL$\mathrm{UR}-\mathrm{V}, 25 \mu \mathrm{m} \times 25 \mu \mathrm{m} / \mathrm{pixel})$ を用い，同社製のソフトウエ ア Image Gauge を用いて寸法計測を行った.

\subsection{TEM を用いたステレオ観察の原理}

Fig. 1 は，ステレオ観察の原理を示した模式図であり，点 $\mathrm{O}$ は試料上の基準点, 点 $\mathrm{P}$ および $\mathrm{Q}$ は試料上の被測定点, 面 XY は入射電子線に垂直であり点 $\mathrm{O}$ を含む面である．X 軸を回転軸として試料を角度 $\theta$ 傾斜することにより，点 $\mathrm{P}$ および点 $\mathrm{Q}$ がそれぞれ点 $\mathrm{P}^{\prime}$ および点 $\mathrm{Q}^{\prime}$ に移動することとな る.ここで, 点 $\mathrm{P}, \mathrm{Q}$ 間の高さの差 $\Delta h$ を求める場合, 点 $\mathrm{P}$ および点 $\mathrm{P}^{\prime}$ の $\mathrm{XY}$ 面での距離 $p$ および $p^{\prime}$ からの高さ $h(\mathrm{p})$ は 次式で与えられる.

$$
h(\mathrm{p})=p^{\prime} / \sin \theta-p / \tan \theta
$$

同様に点 $\mathrm{Q}$ に対する高さ $h(\mathrm{q})$ は次式で与えられる.

$$
h(\mathrm{q})=q^{\prime} / \sin \theta-q / \tan \theta
$$

従って, 点 $\mathrm{P}, \mathrm{Q}$ 間の高さの差 $\Delta h$ は, 式 (1), (2)より,

$\Delta h=|h(\mathrm{p})-h(\mathrm{q})|=\left|\left(p^{\prime}-q^{\prime}\right) / \sin \theta-(p-q) / \tan \theta\right|$ となる。

TEM を用いたステレオ観察により，Fig. 2 に示すような 形状をもつ試料の厚さ $t$ を計測する場合，まず，電子線の入 射方向と試料の厚さ方向が平行となるように試料の方位を合

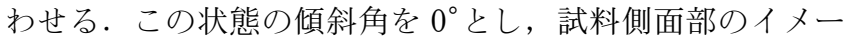
ジングプレート上に投影された長さ $l$ を計測する. 次に, 試 料を $\alpha^{\circ}$ 傾斜し, 同様に試料側面部の投影された長さ $l^{\prime}$ を計 測する. 式 $(3)$ より, 試料の厚さ $t$ は, 次式で求められる.

$$
t=l^{\prime} / \sin \alpha-l / \tan \alpha
$$

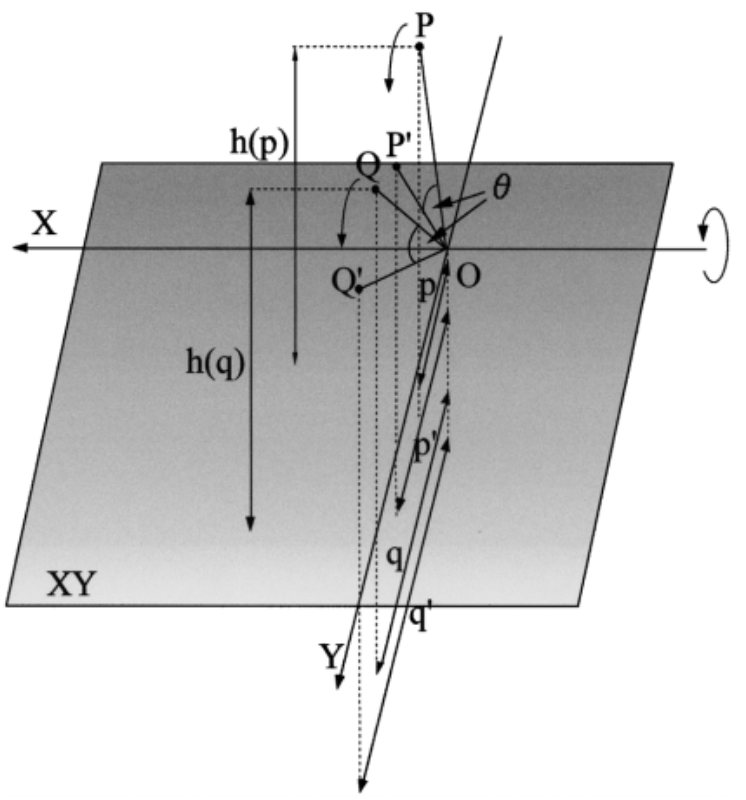

Fig. 1 Principle of stereoscopic observation.

\section{3 幾何学形状を利用したへマタイト微粒子の厚さ評価}

Fig. 3 は，電子線を粒子の主平面である $\{0001\}$ 面に対し て垂直に入射した際に得られる六角盤状へマタイト微粒子の TEM 像と電子回折図形である. Fig. 3(a)より, このへマタ イト微粒子は正六角形の盤状の形態であり, さらに, Fig. 3 (b)に示した電子回折図形から, 粒子は単結晶であり, 六 回の対称性を有していることがわかる。この平面 TEM 像の 観察結果とともに，これまでに報告されている TEM による 詳細な形態評価の結果8,9) を考え合わせると, ヘマタイト微 粒子は主平面および側面がそれぞれ $\{0001\}$ 面および $\{1012\}$ 面から構成された Fig. 4 に示すような形状であり, 主平面 $\{0001\}$ と側面 $\{1012\}$ のなす角度 $\phi$ の值は $57.6^{\circ}$ である．この $\phi$ の值と微粒子のエッジ部がくさび状であることから，この 六角盘状へマタイト微粒子の厚さ $t$ は, 次式より求めること ができる.

$$
t=d \cdot \tan \phi
$$

ここで， $d$ は粒子のエッジ部の幅である.よって, Fig. 3(a) に示すような TEM 像から粒子の各辺についてそれぞれ $d$ を 求め，式（５）から粒子の厚みを評価した.

\section{4 ステレオ観察によるへマタイト微粒子の厚さ評価}

ステレオ観察の具体的な手順として，まず，六角盤状へマ タイト微粒子の主平面である $\{0001\}$ 面に対して電子線が垂 直に入射するように, 微粒子の結晶方位を合わせる. この状 態の傾斜角を $0^{\circ}$ とし， $0 \sim 35^{\circ}$ の傾斜範囲において $5^{\circ}$ 毎に微 粒子の TEM 像をイメージングプレートに撮影した。 また, ステレオ観察における寸法計測で重要な試料の傾斜軸は，表 面が平坦である $\mathrm{Si} ウ ェ$ ウ張り合わせた断面試料を用い, その張り合わせした面を試料ホルダーの長手方向と平行とな るように支持したあと，TEM 観察により張り合わせ面の方 向を確認することにより決定を行った．本研究で用いた六角 盤状へマタイト微粒子には, Fig. 3 に示すように明瞭な頂点 が存在することから，これらの頂点を一対のステレオ像間に おける対称点の同定に利用した. ステレオ観察における試料 厚みの具体的な計測方法を Fig. 5 に示す。 まず，辺 $\mathrm{AB}$ お (a) Tilting Angle: $0^{\circ}$
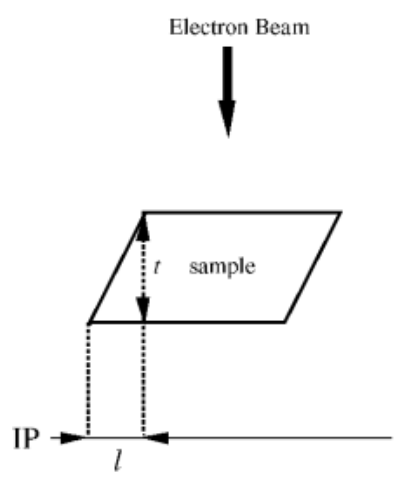

(b) Tilting Angle: $\alpha^{\circ}$

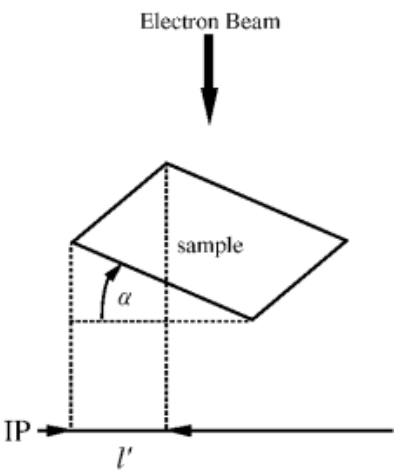

Fig. 2 Schematic illustration showing the measurement of sample thickness of a platelet-type hematite particle by stereoscopic observation using TEM. 
よび辺 $\mathrm{CD}$ のそれぞれの中点を点 $\mathrm{N}$ および点 $\mathrm{M}$ とする. 次 に, 中点 $\mathrm{M}$ から TEM 像上の傾斜軸の方向を示す直線に対 して垂線を下ろし，辺 $\mathrm{EF}$ との交点を点 $\mathrm{G}$ とする。 辺 $\mathrm{MG}$

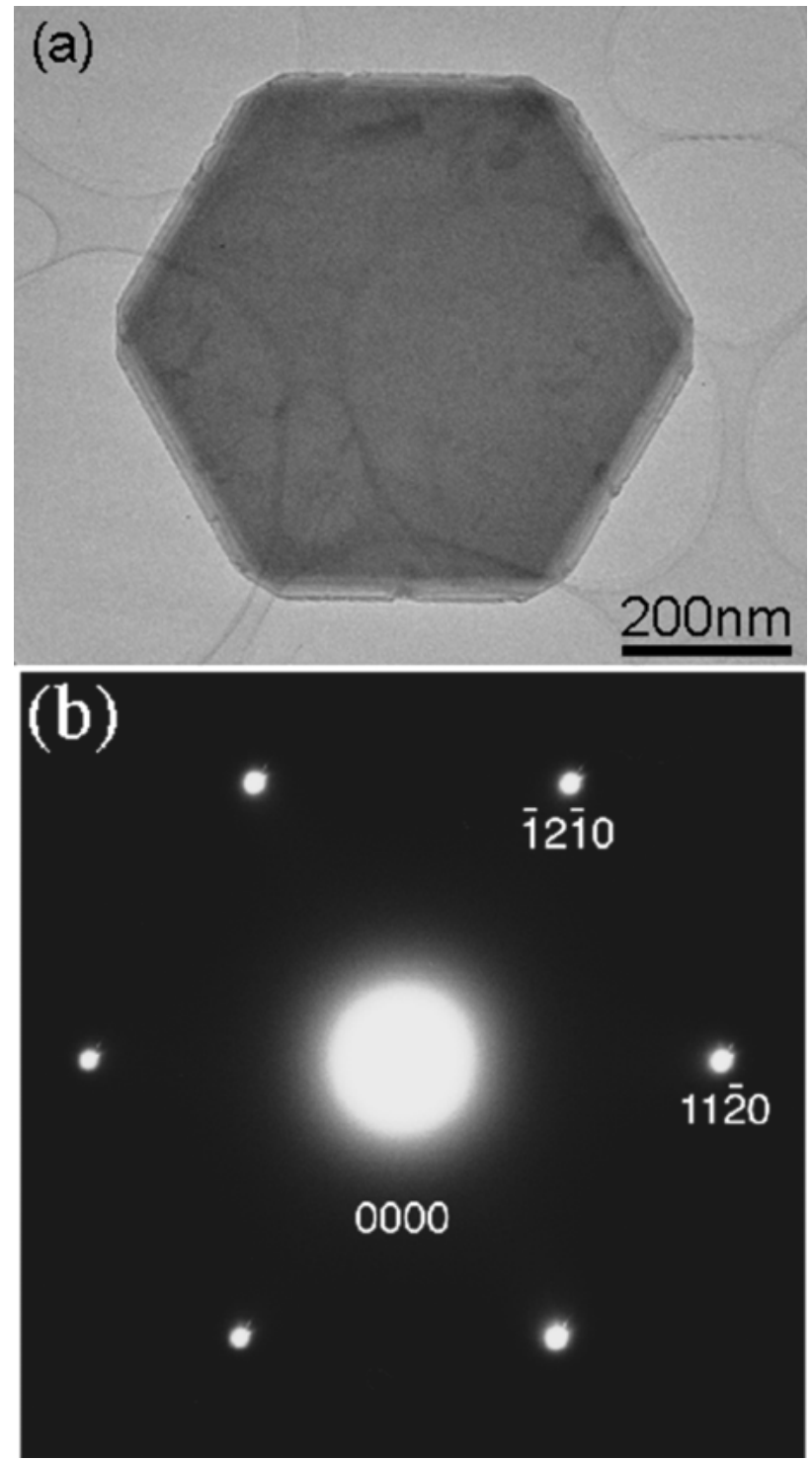

Fig. 3 TEM image (a) and an electron diffraction pattern (b) of a platelet-type hematite particle. The incident electron beam is parallel to the $[0001]$ direction of the hematite particle.
と辺 $\mathrm{MN}$ とのなす角を $\varepsilon$ とすると辺 $\mathrm{MG}$ の長さは次式で求 めることができる.

$$
\overline{\mathrm{MG}}=\overline{\mathrm{MN}} / \cos \varepsilon
$$

粒子を $\tau^{\circ}$ 傾斜した後の辺 $\mathrm{MG}$ の長さを $\overline{\mathrm{MG}^{\prime}}$ とすると式 (4)より，ステレオ観察によるエッジ部の厚さ $t_{\mathrm{s}}$ は次式で 求められる.

$$
t_{\mathrm{s}}=\overline{\mathrm{MG}^{\prime}} / \sin \tau-\overline{\mathrm{MG}} / \tan \tau
$$

以上の方法により，傾斜角 $0^{\circ}$ と各傾斜角において撮影され た TEM 像から六角盤状へマタイト微粒子の厚みを評価した.

\section{3. 結果および考察}

Fig. 6 は，傾斜角 $0 \sim 35^{\circ}$ の範囲に拈いて $5^{\circ}$ 間隔で傾斜さ

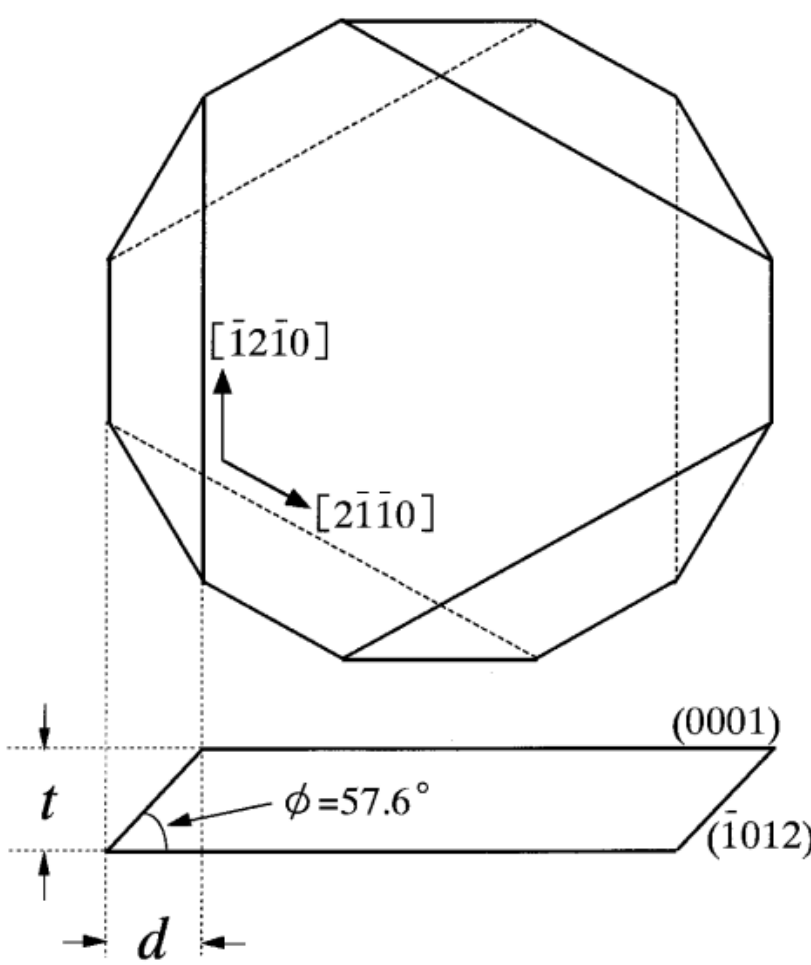

Fig. 4 Schematic illustration showing the morphology of a platelet-type hematite particle. The specimen thickness $t$ can be obtained by measuring the edge width of the particle.

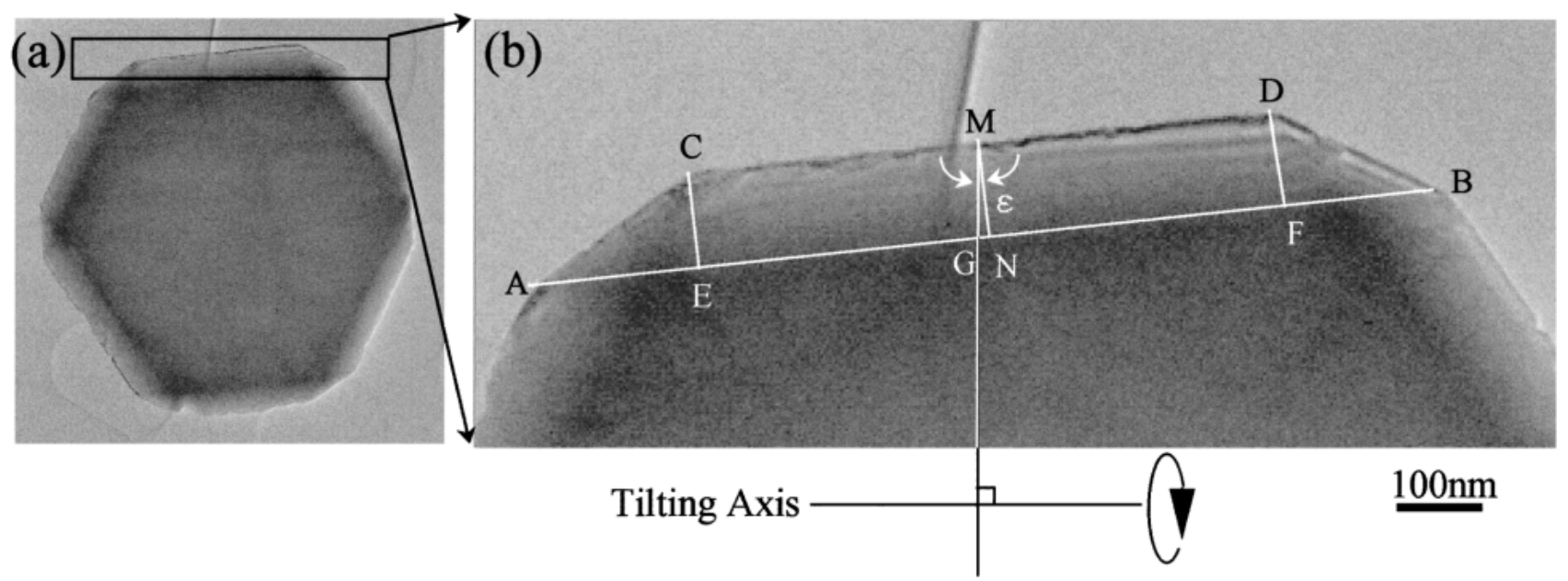

Fig. 5 Measurement procedure of sample thickness of a platelet-type hematite particle by stereoscopic observation using TEM. 

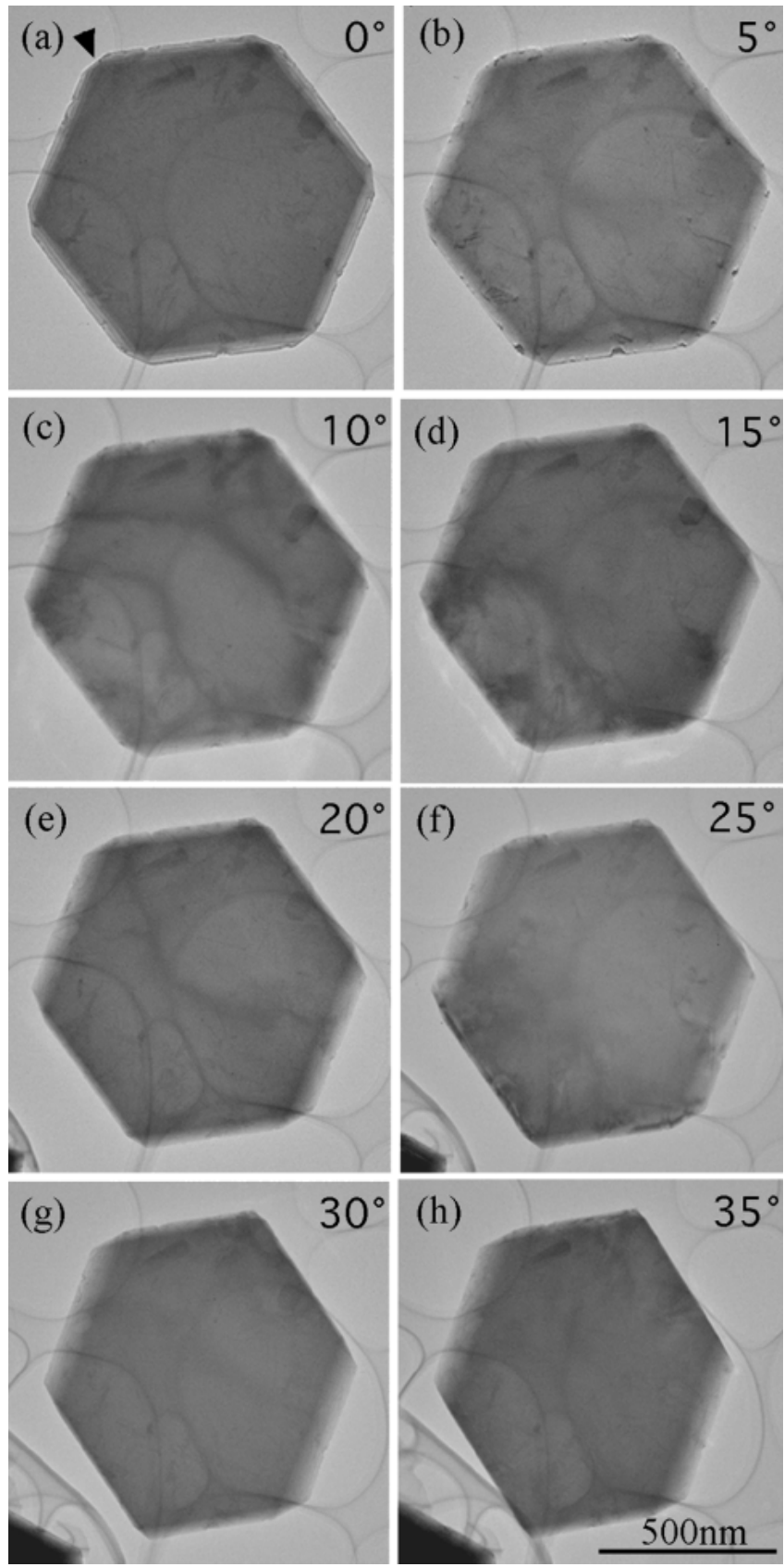

Fig. 6 TEM images of a platelet-type hematite particle obtained with a tilt angle from $0^{\circ}$ to $35^{\circ}$.

せた際の六角艋状へマタイト微粒子の TEM 像である. TEM 像のフォーカスは全て Fig. 6 (a)中の矢印で示したエ ッジ部に合わせて撮影を行った。傾斜角 $35^{\circ}$ の TEM 像 (Fig. $6(\mathrm{~h}))$ では, ディフォーカス量が非常に大きいため, 試料の エッジ部にフレネルフリンジに対応した白あるいは黒の縞状 のコントラストが発生していることがわかる。このフレネル フリンジは, 粒子のエッジ部分を不明瞭にするため, ステレ 才観察における寸法計測の精度を低下させる原因のひとつで あると考えられる。

Fig. 7 は，ステレオ観察により計測した厚さ $t_{\mathrm{s}}$ と微粒子 の幾何学的形状を利用した方法から計測される厚さ $t_{\mathrm{g}}$ との 関係を示す傾斜角 $5^{\circ}$ (a) 抢よび $20^{\circ}$ (b) に打けるグラフである.

Fig. $7(\mathrm{a})$ より傾斜角 $5^{\circ}$ では， $t_{\mathrm{g}}$ と $t_{\mathrm{s}}$ の間の対応に扔いてバ
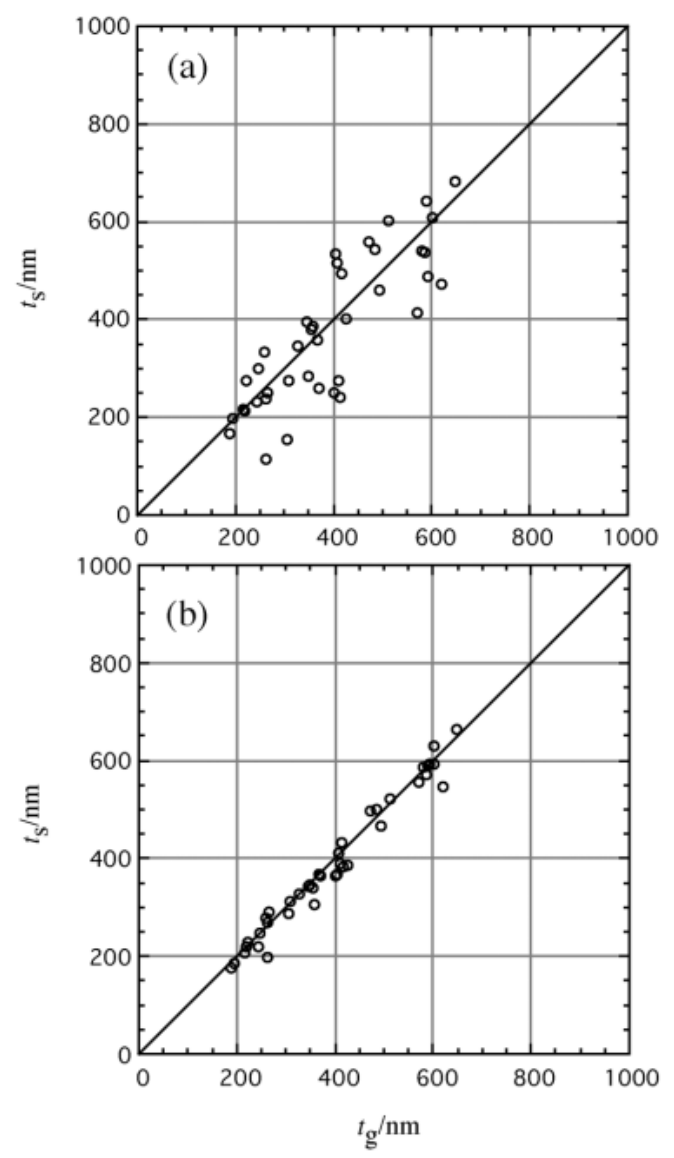

Fig. 7 The relationship between $t_{\mathrm{s}}$ and $t_{\mathrm{s}}$ at tilt angle (a) $5^{\circ}$ and (b) $20^{\circ}$. $t_{\mathrm{s}}$ and $t_{\mathrm{g}}$ show the thickness of the specimen, obtained respectively by stereoscopic observation and geometric calculation taking the particle shape into consideration.

Table 1 Standard deviation of difference between $t_{\mathrm{s}}$ and $t_{\mathrm{g}}$.

$\begin{array}{lrrrrrr}\text { Tilting angle (degree) } & 5 & 10 & 15 & 20 & 25 & 30\end{array}$

$\begin{array}{lllllll}\text { Standard deviation }(\%) & 14.5 & 9.6 & 5.8 & 4.8 & 7.9 & 6.2\end{array}$

ラツキがみられるが，傾斜角 $20^{\circ}$ では， $t_{\mathrm{g}}$ と $t_{\mathrm{s}}$ は試料の厚さ に依存することなく両者は良く一致していることがわかる (Fig. 7(b)).

Table1 は，各傾斜角での $t_{\mathrm{g}}$ と $t_{\mathrm{s}}$ の間のずれ量 $\left(\left|t_{\mathrm{s}}-t_{\mathrm{g}}\right| / t_{\mathrm{g}}\right.$ $\times 100(\%))$ 標準偏差である.この表から，傾斜角 50 では， $t_{\mathrm{g}}$ と $t_{\mathrm{s}}$ の間のずれ量の標準偏差の值は $14.5 \%$ と大きな值を 示しているものの，傾斜角の増大とともに徐々に減少し，傾 斜角 $20^{\circ}$ に抢いて，その值は最小となる。ささらに $25 \sim 30^{\circ}$ の 傾斜角では，ずれ量の標準偏差の值はほぼ一定の值を示して いる，以上の検討から，TEM を用いたステレオ観察におい て最も高い計測精度が得られる傾斜角度は $20^{\circ}$ であることが 明らかとなった。

傾斜角度が小さい場合の $t_{\mathrm{g}}$ と $t_{\mathrm{s}}$ の間のずれの発生原因 は，ステレオ観察により得られた計測データから, 試料厚み を算出するために利用する式 $(7)$ 中で, $\sin \tau, \tan \tau$ が非常に 小さい值を取るために，へマタイト微粒子のエッジ部分の測 定時に発生すると考えられる計測誤差が拡大することによる ものと推定される. 従って, 傾斜角度が小さい場合の $t_{\mathrm{g}}$ と 
$t_{\mathrm{s}}$ の間のずれ量を低減するためには，より精密な寸法計測が 必要となる。一方，傾斜角度が大きい場合，TEM 像におけ る像の歪みやぼけ, 試料エッジ部でのフレネルフリンジの発 生に伴なう寸法計測時の誤差がずれの発生原因と推定され た. 従って，傾斜角度が大きい場合に高い精度で寸法計測を 実施するためには，被測定点に対して正確にフォーカスを合 わせることが必要となる. なお, 傾斜角が大きい場合, 試料 の形態によっては測定が困難となることがあるため, 試料の 形態から傾斜可能な角度範囲を事前に検討する必要があると 考えられる.

\section{4. 結 論}

TEM とイメージングプレートを用いたステレオ観察によ り，六角盤状へマタイト微粒子の厚みを評価し，粒子の幾何 学形状から求められる試料厚みとの比較から, ステレオ観察 の計測精度について検討を行った．主な結果は，以下の通り である。

（1） ステレオ観察により評価される六角盤状へマタイト微 粒子の厚さ $t_{\mathrm{s}}$ と粒子の幾何学的な形状を利用して求めた厚 さ $t_{\mathrm{g}}$ との相関を検討し，傾斜角 $0 \sim 35^{\circ}$ の範囲において，傾 斜角 $20^{\circ}$ で両者のずれの標準偏差は $4.8 \%$ となり, 最も高い 計測精度が得られることがわかった。
(2) $20^{\circ}$ より小さい傾斜角度における $t_{\mathrm{s}}$ と $t_{\mathrm{g}}$ の間のずれ量 は，六角盤状へマタイト微粒子のエッジ部分の幅をステレオ 観察により評価する際に発生する測定䛊差に起因しているも のと考えられた。一方， $20^{\circ}$ より大きい傾斜角度における両 者のずれは, 試料エッジ部でのフレネルフリンジの発生や TEM 像の歪みなどに伴う寸法測定時の測定誤差が主な原因 であると考えられた。

\section{文献}

1) D. Shindo and K. Hiraga: High-Resolution Electron Microscopy for Materials Science, (Kyoritsu Shuppan, 1996). (in Japanese)

2) M. Kiritani: Denshi Kenbikyo 16 (1981) 71-81. (in Japanese)

3) N. Mori, T. Oikawa, T. Katoh, J. Miyahara and Y. Harada: Ultramicroscopy 25 (1988) 195-202.

4) T. Oikawa, N. Mori, N. Tanaka, Y. Harada and M. Ohnishi: J. Electron Microsc. 39(1990) 437-443.

5) D. Shindo, K. Hiraga, T. Oikawa and N. Mori: : J. Electron Microsc. 39(1990) 449-453.

6) D. Shindo, T. Oku, J. Kudoh and T. Oikawa: Ultramicroscopy 54 (1994) 221-228.

7) T. Sugimoto, S. Waki, H. Itoh and A. Muramatsu: Colloids Surf. A 109 (1996) $155-165$.

8) D. Shindo, B.-T. Lee, Y. Waseda, A. Muramatsu and T. Sugimoto: Mater. Trans., JIM 34(1993) 580-585.

9) D. Nishino, A. Nakafuji, J.-M. Yang and D. Shindo: ISIJ Int. 38(1998) 1369-1374. 